ISSN 0258-7122

Bangladesh J. Agril. Res. 38(3): 373-387, September 2013

\title{
ASSESSING APHID INFESTATION IN INDIAN MUSTARD (Brassica juncea L.) UNDER PRESENT AND FUTURE CLIMATE SCENARIOS
}

\author{
B. BAPUJI RAO ${ }^{1 *}$, V. U. M. RAO ${ }^{2}$, LINITHA NAIR ${ }^{3}$ \\ Y. G. PRASAD ${ }^{4}$, A. P. RAMARAJ ${ }^{5}$ AND C. CHATTOPADHYAY ${ }^{6}$
}

\begin{abstract}
Mustard (Brassica juncea L.) production in India suffers from aphid, Lipaphis erysimi (Kaltenbach), infestation considerably. Role of weather on the incidence and development of mustard aphids was assessed from experimental data from six north Indian locations. Aphid appearance and population build up was found to be regulated by temperature and time to attain peak population was relatively short in warm humid climates than in cool climates. Aphids appeared generally when the accumulated thermal time ranged between 810-847 and diurnal temperature range had a key role on the pest build up. Functional relations developed from the present study between aphid incidence and peak population using previous weeks weather and pest data for majority of the locations could be used for taking of any prophylactic/control measures. Projections on aphid population in future climates using generated weather variables indicated that warming may not increase aphid population at all locations uniformly.
\end{abstract}

Keywords: Indian mustard, aphids, climate change, forewarning models.

\section{Introduction}

Among the Brassica group of oilseed crops, Indian mustard occupies considerably large acreage placing the country on the top both in acreage and production of rapeseed and mustard in Asia. Rapeseed and mustard are cultivated in an area of 56 lakh ha with a production of 66 lakh tonnes and with an average yield of $1182 \mathrm{~kg} / \mathrm{ha}$ (DACNET, 2009-10). A major chunk of (74.3\%) of irrigation area under oilseeds is represented by rapeseed-mustard. Mustard average yields in India is low compared to the other countries where it is grown. Among other factors like rainfed cultivation, the yields are stated to be low mainly because of aphid infestation. The avoidable yield losses due to aphids are anywhere between 20 to 50 percent and in extreme conditions, the yield losses could be as high as 78 percent (Prasad and Phadke, 1983). Several studies have indicated that weather plays an important role on the aphid appearance, multiplication and disappearance (Srivastava and Srivastava, 1972; Roy, 1975; Jitendra Kumar et al., 1999; Srivastava, 1999; Vekaria and Patel, 2000). A

\footnotetext{
${ }^{1-4}$ Central Research Institute for Dryland Agriculture, Santoshnagar, Hyderabad- 500059 ,

${ }^{5}$ Agroclimate Research Centre, TNAU, Coimbatore - 641 003, ${ }^{6}$ Indian Institute of Pulses Research, Kanpur - 208 024, Uttar Pradesh, India.

*Corresponding author: bapujiraob2002@yahoo.com, bapujirao@crida.in.
} 
variety of field and laboratory studies indicate that insect abundance increases with rising temperatures (Cannon, 1998; Bale et al., 2002) and the effect of global warming on plant insect interactions has largely been projected to increased herbivore pressure on plants (Coley, 1998 and Bale et al., 2002). Two modelling studies concluded that temperature was tightly linked with the density of aphids or other sucking pests (Zhou et al., 1997 and Whittaker and Tribe, 1998). Bale et al. (2002) concluded interestingly that increased temperature could also decrease growth of some aphids species depending on their thermal requirements and host specificity. We studied here the changes in aphid population through observed variations in weather parameters under present climates and tried to project population of mustard aphid under global warming using statistical approaches quantifying the variability. However, indirect effects of temperature via changes in crop phenology, increased predator activity are assumed constant. The study further assumes no change in the $\mathrm{CO}_{2}$ levels. An attempt has thus been made in this paper to predict the appearance and development of aphids on mustard crop for northern Indian conditions based on weather which ultimately may culminate into a Decision Support System (DSS) for the management of aphids under present and future climates.

\section{Materials and Method}

Field experiments were conducted at six locations in northern India during rabi season with mustard cultivar varuna. The treatment details i.e., dates on which the crop was sown in different years at different locations are presented in table 1. For each treatment 3 plots were maintained as replications and standard agronomic practices except plant protection measures were followed to ensure optimum plant vigour during the experimental period. Aphid population was recorded on $10 \mathrm{~cm}$ shoot apex on main stem on 10 plants in each replication at 3 - day intervals (twice a week i.e., Tuesday and Friday). Aphid count from each observation was averaged and converted to weekly averages per plot for each date of sowing. Daily meteorological data on maximum temperature $\left(\mathrm{T}_{\max }\right)$ and minimum temperature $\left(\mathrm{T}_{\min }\right)$; morning relative humidity $\left(\mathrm{RH}_{\max }\right)$ and afternoon relative humidity $\left(\mathrm{RH}_{\min }\right)$; wind speed (WS); hours of bright sunshine (SS); rainfall $(\mathrm{RF})$ and open pan evaporation (EVP) for all locations were collected from adjacent standard meteorological observatories. Daily data were then aggregated into weekly mean values except for rainfall and open pan evaporation.

\section{Data analysis and model fitting}

\section{Estimation of degree-days for first and peak appearance}

Insects, like plants and many other organisms, are dependent on temperature to develop. These organisms begin developing when the temperature exceeds the 
lower developmental threshold or base temperature. The rate of development increases as the temperature exceeds the base temperature and decreases as the temperature drops. Growing Degree Day (GDD) is widely used than the calendar method for estimating insect development and timing management strategies (Kowalsick and Clark, 2006 and Murray, 2008). Accumulated GDD (AGDD) was computed and its role on incidence of aphid was analysed.

Table1. Details of the field experimentation.

\begin{tabular}{|c|c|c|c|}
\hline $\begin{array}{l}\text { Name of the } \\
\text { location }\end{array}$ & $\begin{array}{l}\text { Geographical } \\
\text { location }\end{array}$ & $\begin{array}{c}\text { Treatments (Date of } \\
\text { Sowing) }\end{array}$ & $\begin{array}{c}\text { Years of } \\
\text { experimentation }\end{array}$ \\
\hline New Delhi & $28^{\circ} 39^{\prime} \mathrm{N} ; 77^{\circ} 13^{\prime} \mathrm{E}$ & $\begin{array}{l}1^{\text {st }} \text { Oct, } 8^{\text {th }} \text { Oct, } 15^{\text {th }} \text { Oct, } \\
22^{\text {nd }} \text { Oct } 29^{\text {th }} \text { Oct, } 5^{\text {th }} \\
\text { Nov } 12^{\text {th }} \text { Nov } 19^{\text {th }} \text { Nov, } \\
26^{\text {th }} \text { Nov }, 3^{\text {rd }} \text { Dec }\end{array}$ & $\begin{array}{l}\text { 2001-02; 2002-03; } \\
\text { 2003-04 }\end{array}$ \\
\hline Udaipur & $25^{\circ} 21^{\prime} \mathrm{N} ; 74^{\circ} 38^{\prime} \mathrm{E}$ & $\begin{array}{l}5^{\text {th }} \text { Oct, } 20^{\text {th }} \text { Oct, } 5^{\text {th }} \text { Nov, } \\
20^{\text {th }} \text { Nov }\end{array}$ & $\begin{array}{l}2004-05 ; 2005-06 \\
2006-07 ; 2008-09 \\
2009-10\end{array}$ \\
\hline Mohanpur & $22^{\circ} 57^{\prime} \mathrm{N} ; 88^{\circ} 20^{\prime} \mathrm{E}$ & $\begin{array}{l}1^{\text {st }} \text { Oct, } 8^{\text {th }} \text { Oct, } 15^{\text {th }} \text { Oct, } \\
22^{\text {nd }} \text { Oct } 29^{\text {th }} \text { Oct, } 5^{\text {th }} \\
\text { Nov, } 12^{\text {th }} \text { Nov, } 19^{\text {th }} \text { Nov, } \\
26^{\text {th }} \text { Nov, } 3^{\text {rd }} \text { Dec, } 10^{\text {th }} \\
\text { Dec, } 17^{\text {th }} \text { Dec }\end{array}$ & $\begin{array}{l}\text { 2001-02; 2002-03; } \\
\text { 2003-04; 2004-05; } \\
\text { 2005-06; 2006-07; } \\
\text { 2007-08; 2008-09 }\end{array}$ \\
\hline Rakh Dhiansar & $32^{\circ} 43^{\prime} \mathrm{N} ; 74^{\circ} 52^{\prime} \mathrm{E}$ & $\begin{array}{l}10^{\text {th }} \text { Oct } ; 25^{\text {th }} \text { Oct } ; 5^{\text {th }} \\
\text { Nov }\end{array}$ & $\begin{array}{l}\text { 2005-06; 2006-07; } \\
\text { 2007-08 }\end{array}$ \\
\hline Palampur & $32^{\circ} 06^{\prime} \mathrm{N} ; 76^{\circ} 03^{\prime} \mathrm{E}$ & \multicolumn{2}{|c|}{$\begin{array}{l}31^{\text {st }} \text { Oct } 1989-90 ; 25^{\text {th }} \text { Oct } 1992-93 ; 25^{\text {th }} \text { Oct } \\
1993-94 ; 22^{\text {nd }} \text { Oct } 1998-99 ; 10^{\text {th }} \text { Oct, } 20^{\text {th }} \text { Oct, } \\
10^{\text {th }} \text { Nov } 2003-04\end{array}$} \\
\hline Bharatpur & $27^{\circ} 12^{\prime} \mathrm{N} ; 7^{\circ} 27^{\prime} \mathrm{E}$ & $\begin{array}{l}1^{\text {st }} \text { Oct, } 8^{\text {th }} \text { Oct, } 15^{\text {th }} \text { Oct, } \\
22^{\text {nd }} \text { Oct, } 29^{\text {th }} \text { Oct, } 5^{\text {th }} \\
\text { Nov }, 12^{\text {th }} \text { Nov, } 19^{\text {th }} \text { Nov, } \\
26^{\text {th }} \text { Nov, } 3^{\text {rd }} \text { Dec }\end{array}$ & $\begin{array}{l}\text { 2001-02; 2002-03; } \\
\text { 2003-04; 2004-05 }\end{array}$ \\
\hline
\end{tabular}

Accumulated growing degree days was derived by using the formula (Iwata, 1984)

$$
\mathrm{AGDD}=\sum_{i=O}^{n}\left(\frac{T \max +T m m}{2}\right)-T B
$$

Where,

$\mathrm{T}_{\max }=$ maximum temperature $\left({ }^{\circ} \mathrm{C}\right)$,

$\mathrm{T}_{\min }=$ minimum temperature $\left({ }^{\circ} \mathrm{C}\right)$ and

$\mathrm{T}_{\mathrm{b}}=$ base temperature $\left({ }^{\circ} \mathrm{C}\right)$. 
A base temperature of $5^{\circ} \mathrm{C}$ was considered for aphid insect in the present analysis to estimate the AGDD required for first appearance of aphid and attainment of peak incidence.

Weekly aphid population data from first appearance till harvest were correlated with the weekly mean values of different meteorological parameters viz., maximum temperature $\left(\mathrm{T}_{\max }\right)$ and minimum temperature $\left(\mathrm{T}_{\min }\right)$; morning relative humidity $\left(\mathrm{RH}_{\max }\right.$ ) and afternoon relative humidity $\left(\mathrm{RH}_{\min }\right)$;rainfall (RF)and open pan evaporation(EVP). Regression analysis was performed between weather parameters having significant correlation and the aphid population.

Based on correlation coefficients between the aphid population and dependent variables under study with the respective weather parameters in different weeks, a composite weather variable $\left(\mathrm{z}_{\mathrm{i}}\right)$ was developed as the weighted sum of the weather variable in different weeks starting from pre-sowing week up to the week of prediction as presented in Eq. 1 (Agrawal et al., 1986; Desai et al., 2004).

$Y=a_{O}+\sum_{i=1}^{p} a_{i} z_{i}+\sum_{i=j}^{p} b_{i j} z_{i j}+e \ldots \ldots .$. Equation 1.

where

$$
\begin{aligned}
& Z_{i}=\sum_{w=1}^{f} r_{i w} x_{i w} \\
& Z_{i j}=\sum_{w=1}^{f} r_{i j w} x_{i w}
\end{aligned}
$$

$\mathrm{Y}=$ Aphid population $/ 10 \mathrm{~cm}$ shoot apex, $x_{i w}$ the value of $i$ th weather parameter in $w^{\text {th }}$ week, $r_{i w}$ the value of correlation coefficient between $\mathrm{Y}$ and $i^{\text {th }}$ weather parameter in $w^{\text {th }}$ week, $r_{i j w}$ the correlation coefficient between $\mathrm{Y}$ and product of $x_{i}$ and $x_{j}$ in $w^{\text {th }}$ week, $p$ the number of weather variables, $f$ the week after sowing when predicted and $e$ the error term.

Similar studies using interaction terms $\left(\mathrm{z}_{\mathrm{ij}}\right)$ were developed as weighted sums of product between two weather variables, weightings being correlation coefficients of dependant variable under study with products of weather variables in respective weeks (Chattopadhyay et al., 2005). Individual effects of weather parameters on crop yields were studied by Jain et al. (1980) and yield forecast models based on weather factors were constructed by Agrawal et al. (1986). A modified statistical model of Jain et al., (1980) as presented in Eq.2 was employed in the present study, considering effects of changes in weather parameter on pest incidence in a given week as a linear function of respective correlation coefficient between pest and weather variable. The trend influence 
considered by Jain et al. (1980) was not considered in the present study as the cultivar and management practices were similar in all the years at individual locations and pest incidences are due to weather influence only.

$$
Y=a+b_{O} \sum_{w=1}^{n} r_{x v(w)} X_{w}+b_{1} \sum_{w=1}^{n} r^{2} x y(w) X_{w}=a+b_{O} Z_{O}+b_{1} Z_{1} . . b_{1} Z_{n} \ldots
$$

(Equation. 2)

Where, $\mathrm{Y}$ is mustard aphid incidence (count); $\mathrm{a}$ and $\mathrm{b}$ are constants; $\mathrm{n}$ is number of weeks up to attainment of peak aphid population; $w$ is week of interest; $X_{w}$ is the value of weather variable under study in $w^{\text {th }}$ week; $r_{x y(w)}$ is correlation coefficient between pest population and weather variable in $\mathrm{w}^{\text {th }}$ week; $\mathrm{Z}$ is generated weather variable.

Forewarning models with different lead periods were developed with previous weather and pest population data as input. The above model (Eq.2) was employed to assess the impact of climatic change in terms of increased temperature on mustard aphid occurence by increasing maximum and minimum temperatures of current weather variables by $1^{\circ} \mathrm{C}$. The influence of enhanced $\mathrm{CO}_{2}$ under climate change scenario on both the aphid and host plant was assumed to be negligible and not considered.

\section{Results and Discussion}

Time taken for the first appearance of aphids and its subsequent attainment of peak population in days from the sowing of mustard crop at different locations as mean \pm SE of different years are presented in Table 2. Large variations could be noticed for both the events. At Mohanpur, aphids appeared and attained peak population levels few days earlier than at other locations. Warm and humid weather conditions prevailed during crop season at Mohanpur than at other locations. The mean maximum temperature during the crop season at Mohanpur was $28.7^{\circ} \mathrm{C}$ which is almost $9^{\circ} \mathrm{C}$ warmer than at Palampur. Minimum temperature at Mohanpur during the crop season, rather than maximum temperature, was considerably high and almost 5 to $8^{\circ} \mathrm{C}$ more than the rest of the locations. These differences in maximum and minimum temperatures might played a role on the incidence and development of aphids across the locations. The AGDD required for the aphids to appear and attain peak population (Table 2) indicated that the aphids appeared between 810-847 AGDD except at Udaipur but for attainment of peak population large variation in AGDD requirement was observed. At Rakh Dhiansar and Palampur the activity of the pest got delayed probably due to the influence of temperature on the crop phenology itself. The occurrence, peak, decreasing, and dispersal of aphid population are dependent on the plant phenological events, observed Chakravarthy and Goutam (2002). In an earlier study, Kundu and Pant (1968) observed the flowering and pod initiation stages as the most favoured by aphids. 
Table 2. Days to and thermal time required for first appearance and attainment of peak aphid population.

\begin{tabular}{l|c|c|c|c}
\hline $\begin{array}{c}\text { Name of the } \\
\text { location }\end{array}$ & $\begin{array}{c}\text { Initial } \\
\text { occurrence } \\
\text { (DAS) }\end{array}$ & $\begin{array}{c}\text { Attainment of } \\
\text { peak population } \\
\text { (DAS) }\end{array}$ & $\begin{array}{c}\text { AGDD required } \\
\text { for initial } \\
\text { occurence }\end{array}$ & $\begin{array}{c}\text { Mean } \pm \text { SE } \\
\text { AGDD required } \\
\text { for attainment of } \\
\text { peak population }\end{array}$ \\
\hline Mohanpur & 50 & 89 & 839 & $1382 \pm 417$ \\
New Delhi & 67 & 95 & 810 & $1053 \pm 237$ \\
RakhDhiansar & 75 & 109 & 830 & $1138 \pm 202$ \\
Udaipur & 65 & 89 & 939 & $1230 \pm 328$ \\
Palampur & 101 & 143 & 847 & $1277 \pm 337$ \\
Bharatpur & 75 & 99 & 836 & $1098 \pm 200$ \\
\hline
\end{tabular}

Table 3. Mean weather conditions prevailed during crop growing season at different locations.

\begin{tabular}{lccccc}
\hline \multicolumn{1}{c}{ Location } & $\operatorname{MAXT}\left({ }^{\circ} \mathrm{C}\right)$ & $\mathrm{MINT}\left({ }^{\circ} \mathrm{C}\right)$ & $\mathrm{RH} \mathrm{1}(\%)$ & $\mathrm{RH} \mathrm{2}(\%)$ \\
\hline Mohanpur & 28.7 & 16.2 & 97.0 & 57.4 \\
Bharatpur & 26.4 & 11.4 & 88.6 & 52.3 \\
New Delhi & 25.1 & 10.9 & 85.8 & 45.1 \\
Palampur & 19.6 & 8.7 & 59.0 & 48.2 \\
Rakh Dhiansar & 23.7 & 9.4 & 90.8 & 50.3 \\
Udaipur & 28.6 & 10.4 & 81.0 & 31.0 \\
\hline
\end{tabular}

Mustard aphid population were correlated with weather parameters and the Pearsons's correlation coefficients are presented in Table 4. A positive and significant correlation with both maximum and minimum temperature was observed at all the locations except Bharatpur. Relative humidity showed negative association at some locations but the association was not consistent across locations. Open pan evaporation showed positive and significant association across the locations and pan evaporation is a manifestation of temperature and relative humidity. A close look at the negative and low values of correlation coefficients between temperature and aphid population for Bharatpur and Udaipur revealed that during the peak pest occurrence period maximum temperature values at both these locations were comparatively very high $\left(30.5^{\circ} \mathrm{C}\right.$ and above), whereas at other stations they were less than $26.6^{\circ} \mathrm{C}$. It is possible that temperature directly reduces aphid growth. Wellings and Dixon (1987) observed direct effects of temperature on the intrinsic rates of aphid populations to be generally inverted $\mathrm{U}$ shaped between 5 and $30^{\circ} \mathrm{C}$, with the optimal temperature varying between species. Although many aphid species may be limited by low temperature, others can have upper thresholds as low as $25^{\circ} \mathrm{C}$ (Harrington et al., 1995). Unfortunately, little is known on the individual effects 
of maximum temperature and minimum temperature as there are hardly any growth chamber studies. At Mohanpur and Udaipur, the association between minimum temperature and aphid population was nonsignificant (Table 4). This could be due to prevalence of mean minimum temperature around $13.8^{\circ} \mathrm{C}$ during the peak occurrence period at these locations as against less than $12^{\circ} \mathrm{C}$ at other locations which might have influenced the aphid population. Contradictory reports exist on this observation and at high latitudes or high elevation sites geographical distribution in aphid population is limited by low rather than high temperature thresholds (Hill and Hodkinson, 1995 and Strathedee et al., 1995). The association between mustard aphid and weather parameters seems to be location and season specific. For example, Gami et al. (2002) observed significant negative correlation with maximum and minimum temperature whilst Ahuja (1990) observed a negative association with maximum, minimum temperatures and sunshine hours. Singh and Singh. (1986) observed a positive effect of the temperature (maximum and minimum), RH (morning and evening) and sunlight on the population of $L$. erysimi, whereas, wind speed and rainfall had negative effect.

Table 4. Pearson's correlation coefficients between weather parameters and peak population of aphids.

\begin{tabular}{l|c|c|c|c|c|c|c|c}
\hline \multicolumn{1}{c}{ Location } & $\begin{array}{c}\text { Tmax } \\
\left({ }^{\circ} \mathrm{C}\right)\end{array}$ & $\begin{array}{c}\mathrm{Tmin} \\
\left({ }^{\circ} \mathrm{C}\right)\end{array}$ & $\begin{array}{c}\mathrm{RH} \text { I } \\
(\%)\end{array}$ & $\begin{array}{c}\mathrm{RH} \text { II } \\
(\%)\end{array}$ & $\begin{array}{c}\mathrm{WS} \\
(\mathrm{kmph})\end{array}$ & $\begin{array}{c}\mathrm{RF} \\
(\mathrm{mm})\end{array}$ & $\begin{array}{c}\mathrm{SSH} \\
(\mathrm{hr})\end{array}$ & $\begin{array}{c}\text { Open pan } \\
\text { Evaporation } \\
(\mathrm{mm})\end{array}$ \\
\hline Udaipur & $0.13^{*}$ & 0.10 & 0.10 & 0.07 & -0.11 & $-0.13^{*}$ & 0.00 & $0.18^{* *}$ \\
New Delhi & $0.19^{* *}$ & $0.29 * *$ & 0.03 & 0.00 & 0.02 & -0.07 & $-0.23^{* *}$ & $0.24^{* *}$ \\
Mohanpur & $0.25^{* *}$ & 0.09 & -0.05 & $-0.30^{* *}$ & 0.09 & 0.13 & $0.16^{*}$ & $0.26^{* *}$ \\
Rakh Dhiansar & $0.72^{* *}$ & $0.57^{* *}$ & $-0.24^{* *}$ & -0.11 & $0.27^{* *}$ & $-0.38^{* *}$ & 0.11 & $0.40^{* *}$ \\
Palampur & $0.18^{* *}$ & $0.32^{* *}$ & $-0.14^{*}$ & $-0.31^{* *}$ & $0.35^{* *}$ & 0.08 & 0.05 & $0.29^{* *}$ \\
Bharatpur & $-0.32^{*}$ & $-0.49^{*}$ & $0.33^{*}$ & -0.032 & $---@$ & 0.14 & $--@$ & $--@$ \\
\hline
\end{tabular}

(@Data on these parameters not available

*Significant at $5 \%$ level **Significant at $1 \%$ level)

Table 5. Thermal time requirement for aphid infestation.

\begin{tabular}{l|c|c|c}
\hline \multirow{2}{*}{\multicolumn{1}{c}{ Location }} & \multicolumn{3}{c}{ AGDD (Mean) } \\
\cline { 2 - 4 } & Initial & Peak & Difference \\
\hline New Delhi & 810 & 1053 & 243 \\
Mohanpur & 839 & 1382 & 543 \\
Palampur & 847 & 1277 & 430 \\
Rakh Dhiansar & 830 & 1138 & 309 \\
Udaipur & 939 & 1230 & 291 \\
\hline
\end{tabular}


Accumulated GDD computed for initial occurrence and attainment of peak population are tabulated (Table 5). AGDD played a least significant role in the mustard aphid occurrence as is evident from the $\mathrm{R}^{2}$ values.

The aphid population both at initial and peak incidence at various locations were computed using the statistical forecast models (Table 6). The variables $Z_{0}$, $\mathrm{Z}_{2}, \mathrm{Z}_{4}$ are simple products of correlation coefficients and absolute values of weather parameters Tmax, Tmin, RH1 respectively. The variables $Z_{1}, Z_{3}, Z_{5}$ are the quadratic function of the same variables. The results showed highly significant relation for Palampur and Rakh Dhiansar for initial and peak occurrences of aphid. The time period required for initial incidence and peak attainment was longer at both these stations compared to other stations. The low coefficient of determination $\left(\mathrm{R}^{2}\right)$ value at Mohanpur was primarily due to the low correlation coefficient with minimum temperature and RH1. The same reason could be extended to low $\mathrm{R}^{2}$ value at Udaipur for peak infestation. Agarwal and Mehta (2007) developed models on similar lines and found good applicability of them at locations like Berhampur, Pantnagar, Hisar, Ludhiana, Kanpur, Morena and at Bharatpur. The coefficient of determination values of their models ranged from 0.56 to 0.99 . The functional relations developed from the present study (Table 6) indicates that the aphid infestation and attainment of peak population could be predicted reasonably well using the weather data of the previous week for Palampur, New Delhi, Bharatpur and Rakh Dhiansar. For taking up any prophylactic and control measure effectively, information on the likely incidence of aphid at least 3-5 days in advance is desirable. Thus, development of a regression model to address this has been attempted here.

\section{Development of forewarning models}

Incidence, development and decline of aphids thus appear to be primarily regulated by temperature and a temperature dependant function can be used to predict on the behaviour of the insect. The aphid incidence, growth and decline in the present study appear to be dependent mainly on the temperature. Based on these results, a forewarning model of aphid infestation and peak attainment is attempted here. A forewarning model should invariably utilize the past weather conditions to predict the infestation and build up, to put it for practical applications. Some studies in the past do attempt to forewarn aphid appearance. For example, Singh and Verma (1990) observed that the minimum and maximum relative humidity of preceding three days of observation were the most important weather variables to increase the aphid population and out of these two, the minimum relative humidity played an important role in increasing the aphid population. In another attempt, when the aphid population along with mean and minimum temperature of one week before the infestation of aphid was involved in regression analysis, the interaction explained nearly 72 percent of the 
variation. A prediction equation on this basis was formulated by Prasad et al. (1984).

Table 6. Functional relations for prediction of aphids from composite weather indices.

\begin{tabular}{|c|c|c|c|c|}
\hline $\begin{array}{l}\text { Name of the } \\
\text { location }\end{array}$ & & Initial & & Peak \\
\hline New Delhi & $\mathrm{R}^{2}=0.63$ & $\begin{array}{l}Y=-186.69+13.5 Z_{0}+ \\
32.3 Z_{1}-2.6 Z_{2}+17.3 \\
Z_{3}+1.2 Z_{4}+21.1 Z_{5}\end{array}$ & $\mathrm{R}^{2}=0.52$ & $\begin{array}{l}Y=-610.3+102.7 Z_{0}- \\
185.3 Z_{1}+110.7 Z_{2}- \\
64.8 Z_{3}+65.9 Z_{4}+ \\
159.4 Z_{5}\end{array}$ \\
\hline Mohanpur & $\mathrm{R}^{2}=0.20$ & $\begin{array}{l}Y=3.07-0.007 Z_{0}+ \\
0.13 Z_{1}-0.008 Z_{2}- \\
0.18 Z_{3}+0.005 Z_{4}+ \\
0.014 Z_{5}\end{array}$ & $\mathrm{R}^{2}=0.16$ & $\begin{array}{l}Y=-318.7+13.6 Z_{0}- \\
94.9 Z_{1}+88.9 Z_{2}+ \\
712.1 Z_{3}+21.3 Z_{4}-22.4 \\
Z_{5}\end{array}$ \\
\hline Palampur & $\mathrm{R}^{2}=0.99$ & $\begin{array}{l}Y=15.8-0.059 Z_{0}- \\
0.211 Z_{1}+0.097 Z_{2}+ \\
0.298 Z_{3}-0.039 Z_{4}- \\
0.06 Z_{5}\end{array}$ & $\mathrm{R}^{2}=0.99$ & $\begin{array}{l}Y=274.3-20.5 Z_{0}- \\
42.1 Z_{1}-4.3 Z_{2}-0.90 Z_{5}\end{array}$ \\
\hline Rakh Dhiansar & $\mathrm{R}^{2}=0.99$ & $\begin{array}{l}Y=-226.05-2.7 Z_{0}+ \\
7.1 Z_{1}+4.0 Z_{2}-12.4 Z_{3} \\
+0.032 Z_{4}+0.64 Z_{5}\end{array}$ & $\mathrm{R}^{2}=0.55$ & $\begin{array}{l}Y=19.5-1.3 Z_{0}-0.79 \\
Z_{1}+1.17 Z_{2}+0.4 Z_{3}+ \\
0.53 Z_{4}+0.04 Z_{5}\end{array}$ \\
\hline Udaipur & $\mathrm{R}^{2}=0.71$ & $\begin{array}{l}Y=-26.3+0.57 Z_{0}- \\
267.7 Z_{1}+11.1 Z_{2}+ \\
517.4 Z_{3}+0.67 Z_{4}+ \\
0.93 Z_{5}\end{array}$ & $\mathrm{R}^{2}=0.15$ & $\begin{array}{l}Y=266.7+8.1 Z_{0}+ \\
17.9 Z_{1}-4.2 Z_{2}- \\
31244.0 Z_{3}+1.2 Z_{4}- \\
20.6 Z_{5}\end{array}$ \\
\hline Bharatpur & $\mathrm{R}^{2}=0.64$ & $\begin{array}{l}Y=228.9+1.2 Z_{0}-2.1 \\
Z_{1}-1.4 Z_{2}+2.3 Z_{3-} \\
0.33 Z_{4}-0.82 Z_{5}\end{array}$ & $\mathrm{R}^{2}=0.62$ & $\begin{array}{l}Y=1561.5+119.3 Z_{0}+ \\
82.4 Z_{1}-183.9 Z_{2}+56.5 \\
Z_{4}-143.9 Z_{5}\end{array}$ \\
\hline
\end{tabular}

(Variables $Z_{0}, Z_{2}$ and $Z_{4}$ are products of correlation coefficients and absolute values of $\mathrm{T}_{\max }, \mathrm{T}_{\min }$ and $\mathrm{RH}_{1} ; \mathrm{Z}_{1}, \mathrm{Z}_{3}, \mathrm{Z}_{5}$ are quadratic function of Tmax, Tmin and $\mathrm{RH}_{1}$, respectively)

This has prompted the present investigators to attempt and develop an aphid forewarning model. Regression studies were carried out between different weather parameters and aphid development rate with lead period ranging from three to seven days and the relations developed are presented in Table 7. The Table 7 presents the functional relations developed utilizing data from all the locations. The high correlation coefficient values and coefficient of determination values suggest that these account for fairly large variability (57\%) in the aphid population build up. On location basis, the forewarning models accounted for $70 \%$ variability in aphid population at Bharatpur, followed by Mohanpur (56\%) and New Delhi (47\%). However, at the other three locations viz., Palampur, Rakh Dhiansar and Udaipur, forewarning the appearance of the pest may not be 
feasible because of the poor $\mathrm{R}^{2}$ values. This may also be partly due to low variability in the data considered at these locations, a resultant of few years of experimentation and few dates of sowing. Development of relations on these lines involving more experimental data may resolve this issue. Nevertheless, the models with high $\mathrm{R}^{2}$ could be used as a tool to forewarn the aphid build up so that whenever a threshold value of the population is attained, chemical control measures could be advocated. Prasad and Chakravarty (2000) proposed a model to estimate aphid population on similar lines using previous week aphid population and weather conditions as input to the model.

Table 7. Mustard aphid early forewarning models with different lead periods.

\begin{tabular}{|c|c|c|c|c|c|}
\hline $\begin{array}{l}\text { Lead } \\
\text { Period }\end{array}$ & Location & Parameters & $\mathrm{r}$ & $\mathrm{R}^{2}$ & Equation \\
\hline 7 Days & Bharatpur & $\begin{array}{l}\text { Pest }(\mathrm{Y}), \\
\text { Pest }\left(\mathrm{Y}_{\mathrm{t}-1}\right), \text { Tmax, } \\
\text { Tmin, Diurnal T } \\
\text { and Tmean }\end{array}$ & 0.84 & 0.70 & $\begin{array}{l}Y=0.806+0.821(\mathrm{Yt}-1)-4.039 \\
(\text { Tmin })-2.010(\mathrm{Di})+4.032 \\
(\text { Tmean })\end{array}$ \\
\hline 6 Days & Mohanpur & $\begin{array}{l}\text { Pest }(\mathrm{Y}), \\
\text { Pest }\left(\mathrm{Y}_{\mathrm{t}-1}\right), \mathrm{Tmax} \text {, } \\
\text { Tmin, Diurnal T } \\
\text { and Tmean }\end{array}$ & 0.75 & 0.56 & $\begin{array}{l}Y=2.071+0.727(\mathrm{Yt}-1)+0.086 \\
(\mathrm{Di})-0.149(\text { Tmean })\end{array}$ \\
\hline 7 Days & New Delhi & $\begin{array}{l}\text { Pest }(\mathrm{Y}), \\
\text { Pest }\left(\mathrm{Y}_{\mathrm{t}-1}\right), \text { Tmax } \\
\text { Tmin, Diurnal T } \\
\text { and Tmean }\end{array}$ & 0.69 & 0.47 & $\begin{array}{l}Y=0.268+0.686(Y t-1)+0.064 \\
(\mathrm{Di})-0.024(\text { Tmean })\end{array}$ \\
\hline 7 Days & Palampur & $\begin{array}{l}\text { Pest }(\mathrm{Y}), \\
\text { Pest }\left(\mathrm{Y}_{\mathrm{t}-1}\right), \text { Tmax } \\
\text { Tmin, Diurnal T } \\
\text { and Tmean }\end{array}$ & 0.44 & 0.19 & $\begin{array}{l}\mathrm{Y}=2.209+0.402\left(\mathrm{Y}_{\mathrm{t}-1}\right)-0.058 \\
(\mathrm{Di})-0.006\left(\mathrm{~T}_{\text {mean }}\right)\end{array}$ \\
\hline 3 Days & $\begin{array}{l}\text { Rakh } \\
\text { Dhiansar }\end{array}$ & $\begin{array}{l}\text { Pest }(\mathrm{Y}), \text { Pest }\left(\mathrm{Y}_{\mathrm{t}-}\right. \\
\text { 1),Tmax, Tmin, } \\
\text { Diurnal T and } \\
\text { Tmean }\end{array}$ & 0.61 & 0.38 & $\begin{array}{l}Y=-4.400-0.261\left(\mathrm{Y}_{\mathrm{t}-1}\right)- \\
5.506(\mathrm{Tmax})-13.307(\mathrm{Tmin})-3.750 \\
(\mathrm{Di})+19.106\left(\mathrm{~T}_{\text {mean }}\right)\end{array}$ \\
\hline 7 Days & Udaipur & $\begin{array}{l}\text { Pest }(\mathrm{Y}), \\
\text { Pest }\left(\mathrm{Y}_{\mathrm{t}-1}\right), \text { Tmax } \\
\text { Tmin, Diurnal T } \\
\text { and Tmean }\end{array}$ & 0.16 & 0.03 & $\begin{array}{l}Y=4.889+0.070(Y t-1)-0.056 \\
(\mathrm{Di})-0.044(\text { Tmean })\end{array}$ \\
\hline 7 Days & Pooled & $\begin{array}{l}\text { Pest }(\mathrm{Y}), \\
\text { Pest }\left(\mathrm{Y}_{\mathrm{t}-1}\right), \text { Tmax, } \\
\text { Tmin, Diurnal T } \\
\text { and Tmean }\end{array}$ & 0.75 & 0.57 & $\begin{array}{l}Y=0.812+0.739(Y t-1 \\
)+0.067(\mathrm{Di})-0.068(\text { Tmean })\end{array}$ \\
\hline
\end{tabular}

( $r$ = correlation coefficient, $\mathrm{R}^{2}=$ coefficient of determination). 
Table 8. Mustard aphid incidence projections at elevated temperatures.

(a) Maximum temperature

\begin{tabular}{l|c|c|c|c|c}
\hline \multirow{2}{*}{$\begin{array}{c}\text { Name of the } \\
\text { location }\end{array}$} & $\begin{array}{c}\text { Time of } \\
\text { occurrence }\end{array}$ & \multicolumn{3}{|c}{ Aphid population (count/10 cm shoot apex $)$} \\
\cline { 3 - 6 } & $\begin{array}{c}\text { Under present } \\
\text { climate }\end{array}$ & $\begin{array}{c}1^{\circ} \mathrm{C} \text { rise in } \\
\mathrm{T}_{\max }\end{array}$ & $\begin{array}{c}2^{\circ} \mathrm{C} \text { rise in } \\
\mathrm{T}_{\max }\end{array}$ & $\begin{array}{c}3^{\circ} \mathrm{C} \text { rise in } \\
\mathrm{T}_{\max }\end{array}$ \\
\hline \multirow{2}{*}{ New Delhi } & Initial & 9.5 & 8.9 & 8.5 & 8.0 \\
& Peak & 180.9 & 195.4 & 210.0 & 224.7 \\
Bharatpur & Initial & 22.9 & 25.6 & 23.3 & 21.0 \\
\multirow{3}{*}{ Mohanpur } & Peak & 200.0 & 204.6 & 209.0 & 213.3 \\
& Initial & 1.4 & 1.3 & 1.3 & 1.2 \\
Palampur & Peak & 152.0 & 174.9 & 197.5 & 220.2 \\
& Initial & 6.9 & 5.8 & 5.6 & 5.0 \\
Rakh Dhiansar & Peak & 41.7 & 31.7 & 22.1 & 12.5 \\
& Initial & 5.8 & 7.7 & 9.8 & 12.0 \\
Udaipur & Peak & 33.6 & 34.0 & 34.6 & 35.1 \\
& Initial & 19.9 & 23.7 & 30.7 & 37.8 \\
& Peak & 117.6 & 115.3 & 112.9 & 110.5 \\
\hline
\end{tabular}

(b) Minimum temperature

\begin{tabular}{l|c|c|c|c|c}
\hline \multirow{2}{*}{$\begin{array}{c}\text { Name of the } \\
\text { location }\end{array}$} & Time of & \multicolumn{4}{|c}{ Aphid population (count/10 cm shoot apex) } \\
\cline { 3 - 6 } & occurrence & $\begin{array}{c}\text { Under present } \\
\text { climate }\end{array}$ & $\begin{array}{c}1^{\circ} \mathrm{C} \text { rise in } \\
\text { Tmin }\end{array}$ & $\begin{array}{c}2^{\circ} \mathrm{C} \text { rise in } \\
\text { Tmin }\end{array}$ & $\begin{array}{c}3^{\circ} \mathrm{C} \text { rise in } \\
\text { Tmin }\end{array}$ \\
\hline \multirow{2}{*}{ New Delhi } & Initial & 9.5 & 12.0 & 14.5 & 17.1 \\
& Peak & 181.0 & 164.2 & 147.3 & 130.4 \\
Bharatpur & Initial & 22.9 & 21.9 & 21.6 & 21.0 \\
& Peak & 199.7 & 239.0 & 278.3 & 317.5 \\
Mohanpur & Initial & 1.4 & 1.3 & 1.2 & 1.1 \\
& Peak & 152.0 & 159.4 & 166.1 & 173.2 \\
Palampur & Initial & 6.9 & 6.1 & 5.3 & 4.6 \\
& Peak & 41.7 & 19.3 & 4.2 & 2.7 \\
Rakh Dhiansar & Initial & 5.8 & 6.9 & 8.1 & 9.2 \\
& Peak & 33.6 & 28.8 & 23.3 & 16.7 \\
Udaipur & Initial & 19.9 & 18.5 & 17.2 & 15.8 \\
& Peak & 117.6 & 115.8 & 113.9 & 112.1 \\
\hline
\end{tabular}

\section{Climatic change assessment}

Experimental manipulation of temperature in order to assess the impacts of climatic changes is expensive. The influence of climatic change assessment in the 
present investigation is made by incorporating increased temperatures in the generated weather variables by $1,2,3^{\circ} \mathrm{C}$ using Eq. 2 to develop models for each location, considering the variability in temperatures alone. Another assumption is constant $\mathrm{CO}_{2}$ levels across the temperature ranges considered. The projections indicated a decrease in aphid population during the initial occurrence and increased population during the peak occurrence period for New Delhi, Mohanpur and Bharatpur whereas the population decreased with increasing maximum temperatures during the peak period at Palampur and Udaipur. Whereas at Rakh Dhiansar the population increased for both initial and peak period with increasing maximum temperature. With an increase in minimum temperatures, the population of aphids were projected to decrease at New Delhi, Palampur, Rakh Dhiansar and Udaipur and the population is likely to escalate in Bharatpur and Mohanpur during the peak period (Table 8a, b). Landin and Wennergren (1987) studied the demography and intrinsic rate of population increase of mustard aphid at different constant temperatures and observed that the rate of increase was greatest at $25^{\circ} \mathrm{C}$. They opined that mustard aphid is more adapted to higher temperatures than the cabbage aphid. The study reinforces the main assertion that warming may not increase aphid abundance at all the locations uniformly. The individual effects of maximum and minimum temperature on the aphid population is observed to be contrasting and diametrically opposite at many locations.

\section{Conclusions}

Appearance of aphids on mustard seems to be largely controlled by temperature and in warm humid locations aphid attained peak population levels earlier compared to relatively cool climates. Diurnal temperature range was also found to play a key role on aphid build up and aphids appeared at most of the locations when the AGDD ranged between 810-847. Functional relations between aphid incidence and peak population using previous weeks weather and pest data for majority of the location could be used for taking of any prophylactic/control measures. Projections on aphid population in future climates using generated weather variables indicated that warming may not increase aphid population at all locations uniformly.

\section{References}

Ahuja, D.B. 1990. Population dynamics of mustard aphid Lipaphis erysimi (Kalt.) on Indian mustard, Brassica juncea (subsp. juncea). Indian J. Plant Prot. 18(8): 233-35.

Agrawal, R., R. C Jain and M. P. Jha. 1986. Models for studying rice crop-weather relationship. Mausam 37(1): 67-70. 
Agrawal, R. and S.C. Mehta. 2007. Weather based forecasting of crop yields, pests and diseases - IASRI models. J. Ind. Soc. Agril. Statist. 61(2): 255-263.

Bale, J. S., G.J. Masters, I.D. Hodkinson, C. Awmack, T.M. Bezemer, V.K. Brown, J. Butterfield, A. Buse, J.C. Coulson, J. Farrar, J.E.G. Good, R. Harrington, S. Hartley, T.H. Jones, R.L. Lindroth, M.C. Press, I. Symrnioudis, A.D. Watt and J.B. Whittaker. 2002. Herbivory in global climate change research: direct effects of rising temperature on insect herbivores. Global Change Biology 8:1-16.

Cannon, R. J. C. 1998. The implications of predicted climate change for insect pests in the UK, with emphasis on non-indigenous species. Global Change Biology 4:785-796.

Chakravarthy, N.V.K and R.D. Gautam. 2002. Forewarning mustard aphid. NATP Project Report. Division of Agricultural Physics, IARI, New Delhi, 63 P.

Chattopadhyay, C., R. Agrawal, Amender Kumar, Y.P. Singh, S.K. Roy, S.A. Khan, L.M. Bhar, N.V.K. Chakravarthy, A. Srivastava, B.S. Patel, B. Srivastava, C.P. Singh and S.C. Mehta. 2005. Forewarning of Lipaphis erysimi on oilseed Brassicas in India- a case study. Crop Protection 24:1042-1053.

Coley, P. D. 1998. Possible effects of climate change on plant/herbivore interactions in moist tropical forests. Climatic Change 39:455-472.

DACNET. 2009-10. http://www.dsd.dacnet.nic.in/

Desai, A.G., C. Chattopadhyay, A. Ranjana, A. Kumar, R.L. Meena, P.D. Meena, K.C. Sharma, M. Srinivasa Rao, Y.G. Prasad and Y.S. Ramakrishna. 2004. Brassica juncea powdery mildew epidemiology and weather based forecasting models for India- a case study. Journal of Plant Diseases and Protection 111: 429-438.

Gami, L.M., J.G. Bapodra, RR. Rathod. 2002. Population dynamics of mustard aphid Lipaphis erysimi (Kaltenbach)in relation to weather parameters Indian Journal of Plant Protection 30: 202-04.

Harrington, R., J.S. Bale and G.M. Tatchell. 1995. Aphids in a changing climate. (In) R. Harrington and N.E. Stork (Eds.). Insects in Changing Environment, Academic Press, London. Pp. 125-155.

Hill, J.K., and I.D. Hodkinson. 1995. Effects of temperature on phenological synchrony and altitudinal distribution of jumping plant lice (Hemiptera: Psylloidea) on dwarf willow (Salix lapponum) in Norway. Ecological Enotomology 20:237-244.

Iwata, F. 1984. Heat Unit Concept of crop maturity. In: Physiological Aspects of Dry Land

Farming. Gupta, U.S (Eds.). Oxford and IBH Publishers, New Delhi. Pp. 351-370.

Jain, R.C., R Agrawal and M.P. Jha. 1980. Effect of climatic variables on rice yield and its forecast. Mausam 31(4): 591-596.

Jitendra Kumar, Y.P. Malik and S.V. Singh. 1999. Forecasting models for outbreak of Lipaphis erysimi on some cultivars of mustard, Brassica juncea. Ind. J Entomol. 61 (1): 59-64. 
Kowalsick, T. and S. Clark. 2006. Using Growing Degree-Days for Insect Pest Management. Information Brochure. Horticulture Research Laboratory, Cornell Cooperative Extension, Cornell University, 4 P.

Kundu, G. G. and N.C. Pant. 1968. Studies on the Lipaphis erysimi (Kalt) with special references to insect plant relationship. Effect of age of plant on susceptibility. Indian J. Entomology 30:169-172.

Landin, J. and U. Wennergren. 1987. Temperature effects on population growth of mustard aphids. Swedish J. Agril. Res. 17(1): 13-18.

Murray, M.S. 2008. Using Degree Days to Time Treatments for Insect Pests. Utah Pests Fact sheet. Utah State University Extension. 5P.

OECD-FAO. 2011. Agricultural Outlook 2011-2020, Chapter 5: Oilseeds and oilseed products.

Prasad, S.K. and K.G. Phadke. 1983. Effect of the period of crop exposure to aphid attack on the yield of brown seeded rapeseed. Ind. J. Agric. Sci. 53(12): 1046-1047.

Prasad, S.K., K.G. Phadke, K.N. Mehrotra. 1984. Forecasting of mustard aphid, Lipaphis erysimi (Kaltenbach) on rapeseed crop. Proc. Indian Nat. Sci. Acad. (B) 50:146-153.

Prasad S.K. and N.V.K. Chakravarty. 2000. In.: Proc Nat. Workshop on Dynamic crop simulation modelling for Agrometorological Advisory Services, (eds, Singh S.V., Horels R.A., Saseendran S.A. and Singh K.K.) Publ. National Centre for Medium Range Weather Forecasting. D.S.T. Govt. of India, New Delhi. 315-320 Pp.

Roy, Pranab. 1975. Population dynamics of mustard aphid, Lipaphis erysimi (Kaltenbach) (Aphididae: Hemiptera) in West Bengal. Indian J. Ent. 37(3): 318-321.

Singh, O. P. and S. N. Verma. 1990. Mustard aphid, Lipaphis erysimi (Kalt.) in Madhya Pradesh - a review. J. Aphidology 4:103-108.

Singh, H. and B. Singh. 1986. In: Proc. Nath. Conf. on key pests of agricultural crops, held at C.D.A. University of Agric. \& Tech., Kanpur, from 21-23 December, 1985, Pp. 117-123.

Srivatsava, A. 1999. Effect of date of sowing and varieties on the incidence of mustard aphid, Lipaphis erysimi (Kalt.) on rapeseed mustard. J. Oilseeds Res. 16(2): 380-381.

Srivatsava, A.S. and J. L. Srivatsava. 1972. Ecological studies on aphid, painted bug and saw fly attacking mustard and rape in India. F.A.O. Plant Prot. Bull. 20:136-140.

Strathedee, A.T., S. Bale, F.C. Strathedee, W.C. Block, S.J. Colson, N.R. Webb and I.D. Hodkinson. (1995). Climatic severity and the response to temperature elevation of arctic aphids. Global Change Biology 1:23-28.

Vekaria, M.V. and G.M. Patel 2000. Screening of promising Brassica and allied genotypes for resistance against mustard aphid, Lipaphis erysimi Kalt. (Homoptera: Aphididae). Applied Biol. Res. 4 (1-2): 75-77. 
Wellings, P.W. and A.F.G. Dixon. 1987. The role of weather and natural enemies in determining aphid outbreaks. (In) Insect Outbreaks. P. Barbosa and J.C. Schultz (Eds.) Academic Press. San Diego, California. Pp. 313-346.

Whittaker, J. B. and N.P. Tribe. 1998. Predicting numbers of an insect (Neophilaenus lineatus: Homoptera) in a changing climate. Journal of Animal Ecology 67:987-991.

Zhou, X., J.N. Perry, I.P. Woiwod, R. Harrington, J.S. Bale, and S.J. Clark. 1997. Temperature change and complex dynamics. Oecologia 112:543-550. 